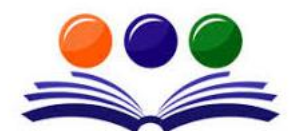

GRAND ACADEMIC PORTAL RESEARCH JOURNALS

\title{
AWARENESS LEVEL AND INVESTMENTS IN MUTUAL FUNDS - A STUDY
}

\author{
Dr. Ashok D. Revankar \\ Principal, Smt. Indira Gandhi First Grade College For Women \\ Sagara, Karnataka, India. \\ ashokrevankar@rediffmail.com
}

\begin{abstract}
To earn a return on surplus and idle funds, generating a specified amount to meet certain goals in future or making provisions for future contingencies investment is necessary. To protect the funds to meet these objectives investment must be made with knowledge and at most care. But large number of people does not have sufficient knowledge about various investment avenues. The awareness level and savings/investment pattern differs from individual to individual. In our country very less number of people invest in mutual funds and awareness level about these is very poor comparatively to other countries. The amount saved must be invested in one or the other security, it should not be kept idle. But to take good investment decision financial knowledge is a must. A disciplined financial plan will definitely help the individuals to take decisions relating to savings and investments to meet their financial goals. Efforts should be made to attract more number of people towards mutual funds to invest their surplus funds.
\end{abstract}

\section{Keywords: Mutual funds, SEBI, RBI, Investments.}

\section{INTRODUCTION}

"Do not save what is left after spending, but spend what is left after saving" - Warren Buffet Now a days large number of savings and investments options are available to an individual like currency, bank deposits, gold, postal savings schemes, real estate, shares, mutual funds etc. In our country generally small investors go for term deposits in banks and postal saving schemes, because they provide safety. But the low interest rates do not provide hedge against inflation and they give them small returns. In the changing scenario people are looking towards shares, mutual funds, etc., for investments which give high returns though they carry high risk.

To earn a return on surplus and idle funds, generating a specified amount to meet certain goals in future or making provisions for future contingencies investment is necessary. To protect the funds to meet these objectives investment must be made with knowledge and at most care. But large number of people does not have sufficient knowledge about various investment avenues. The awareness level and savings/investment pattern differs from individual to individual.

\subsection{Objective of the study}

Understanding the savings and investment pattern and an assessment of their awareness level will help in understanding the financial behaviour of the individuals. Bank deposits, postal - instruments, life insurance products, real estate, gold, pension funds, stocks, bonds, mutual funds etc., are the popular instruments for investment. Safety, liquidity and returns are the three important factors which are considered by the investors before investment is made. In our country very less number of people invest in mutual funds and awareness level about these is very poor comparatively to other countries. Therefore, an attempt is made to understand the behavioral aspect of investors in general and assess the mutual fund conceptual awareness level among the respondents in Sagar town in Shivamogga district of Karnataka in particular. The other objectives are as follows:

○ To assess the socio-economic background of the investors in the study area.

- To assess the investors savings and investment objectives and asset preference pattern.

- To assess their awareness level about the mutual funds.

\subsection{Methodology}

The present study, for its analysis, mainly depends on primary data. The necessary data are collected through a schedule administered in 80 investors and non-investors randomly selected in Sagar town in Shivamogga district of Karnataka state. 


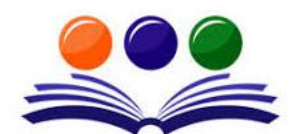

GRAND ACADEMIC PORTAL RESEARCH JOURNALS
A GLOBAL JOURNAL OF SOCIAL SCIENCES

( ISSN - 2581-5830 )

Impact Factor: SJIF - 4.998, IIFS - 4.375

\section{CONCEPT OF MUTUAL FUND}

"Little drops of water, makes a multi Ocean"- on this principle mutual funds works. A mutual fund is a type of collective investment scheme that pools money from large number of investors and invests systematically in stocks, bonds and other securities. Mutual funds are professionally managed by the fund managers. They collects the savings from number of small investors, invest them in corporate and Government securities, earn income inform of dividends, interest in addition to capital appreciation. Those who do not have enough knowledge to invest in shares and debt instruments directly, can invest in these financial assets indirectly through mutual funds. So many players came in to the field and numerous schemes are offered by them. Basically there are two types of mutual funds namely open ended schemes and close ended schemes. Based on these two, various types of mutual funds are available to the investors.

\subsection{Growth of Mutual Funds in India}

The growth of mutual funds in India can be seen in six phases;Phase - 1 1963-1987 : Unit Trust of India[UTI] was established by the Reserve Bank of India in 1963. This was the only entity to offer few mutual fund schemes till 1986.

Phase - 2 1987-1993 : During this period public sector banks, insurance companies were allowed to set up mutual funds.

Phase - 3 1993-1996 : Private sector businesses were allowed to enter this field from 1993 onwards, as a result wide choice of mutual funds are available to the public.

Phase - 4 1996-2003 : From 1996 onwards Securities and Exchange Board of India[SEBI] becomes the regulating authority. To protect the interest of the investors, particularly retail investors, SEBI has brought so many regulations as reform measures.

Phase - 5 2003-2006 : UTI was split in to two separate entities. It led to further strong growth in the field of mutual funds.

Phase - 62006 onwards : Because of liberalization, foreign owned fund managers began entering the market and 2006 onwards have seen significant growth of mutual funds.

Mutual fund industry has shown a healthy growth over the last 20 to 25 years. Indian mutual fund industry has grown 12.5 per cent annually on an average for the last 10 years.

The assets managed by mutual funds and the number of accounts (folios) are stated in Table-1.

Table 1

Assets Managed by Mutual Funds and Number of Folios

\begin{tabular}{|c|c|c|c|}
\hline Period & $\begin{array}{c}\text { Amount } \\
\text { (Rs.in crores) }\end{array}$ & $\begin{array}{c}\text { Growth } \\
\text { (in percentage) }\end{array}$ & $\begin{array}{c}\text { No. of Folios } \\
\text { (in crores) }\end{array}$ \\
\hline March 2009 & $4,17,300$ & -17 & 4.76 \\
\hline March 2010 & $6,13,979$ & 47 & 4.80 \\
\hline March 2011 & $7,00,538$ & 14 & 4.72 \\
\hline March 2012 & $6,64,792$ & -5 & 4.65 \\
\hline March 2013 & $8,16,657$ & 23 & 4.28 \\
\hline July 2014 & $10,48,846$ & 28 & 3.95 \\
\hline July 2015 & $13,18,598$ & 26 & 4.17 \\
\hline July 2016 & $15,73,220$ & 19 & 4.77 \\
\hline July 2017 & $20,42,166$ & 30 & 5.54 \\
\hline July 2018 & $23,26,000$ & 14 & 7.13 \\
\hline March 2019 & $24,58,000$ & 6 & 8.25 \\
\hline Feb. 2020 & $28,29,000$ & 15 & 9.12 \\
\hline March 2020 & $24,71,000$ & -9 & 8.97 \\
\hline
\end{tabular}

From the data it is clear that the growth of Indian mutual fund industry is visible both in terms of assets managed by the mutual funds and number of accounts. From 2010 to 2020 assets managed by mutual funds has grown nearly 4 times and the number of investors accounts almost doubled. But compare to the total population of India, the percentage of investors in mutual funds was just 3.9 percent in 2010 and 6.59 percent in 2020. Among nearly 136 crore population, 75 crores (55 percent) are having bank accounts and 35 crore people (26 percent) are with insurance companies. These figures prove that people are still looking towards banks, insurance products, postal savings etc. Stocks, mutual funds are not their preferred avenues for investments and they are not attracted towards these instruments. 


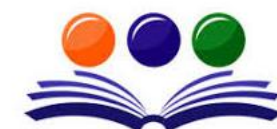

GRAND ACADEMIC PORTAL RESEARCH JOURNALS
A GLOBAL JOURNAL OF SOCIAL SCIENCES

( ISSN - 2581-5830 )

Impact Factor: SJIF - 4.998, IIFS - 4.375

\section{FINDINGS AND ANALYSIS}

Based on the objectives of the study, the work was undertaken. Accordingly, the findings and analysis of the data are presented here. In Table 2, distribution of the respondents by demographic factors is stated.

Table - 2

Distribution of The Respondents by Demographic Factors

\begin{tabular}{|c|c|c|c|}
\hline & 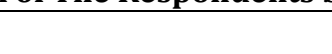 & Number & Percentage \\
\hline \multirow[t]{2}{*}{ Sex } & Male & 56 & 70.00 \\
\hline & Female & 24 & 30.00 \\
\hline \multirow[t]{4}{*}{ Age } & Below 30 Years & 14 & 17.50 \\
\hline & $31-40$ Years & 18 & 22.50 \\
\hline & $41-50$ Years & 24 & 30.00 \\
\hline & Above 50 Years & 24 & 30.00 \\
\hline \multirow[t]{2}{*}{ Marital Status } & Married & 68 & 85.00 \\
\hline & Un-married & 12 & 15.00 \\
\hline \multirow[t]{4}{*}{ Family Income } & Less than Rs. $2,00,000$ & 8 & 10.00 \\
\hline & Rs. $2,00,000-5,00,000$ & 22 & 27.50 \\
\hline & Rs.5,00,000-10,00,000 & 30 & 37.50 \\
\hline & Above Rs.10,00,000 & 20 & 25.00 \\
\hline \multirow[t]{6}{*}{ Savings } & No savings at all & 00 & 00.00 \\
\hline & Less than Rs.1,00,000 & 14 & 17.50 \\
\hline & Rs. $1,00,000-2,00,000$ & 18 & 22.50 \\
\hline & Rs. $2,00,000-3,00,000$ & 22 & 27.50 \\
\hline & Rs.3,00,000-4,00,000 & 18 & 22.50 \\
\hline & More than Rs.4,00,000 & 8 & 10.00 \\
\hline
\end{tabular}

It is evident from the Table 2 that, among 80 respondents, 14 (17.50 per cent) respondents save less than Rs.1,00,000, 18 (22.50 per cent) save between Rs.1,00,000 -2,00,000, 22 (27.50 per cent) save between Rs.3,00,000 -4,00,000 and only 8 (10 per cent) save more than Rs.4,00,000. It is clear from the above that, all the respondents save major portion of their income to meet their financial goals. It is a good sign from the view point of investors because, the whole amount earned is not spent and the habit of saving is inculcated.

\subsection{Savings Objectives}

It is true that, the objectives of savings and investments differ from individual to individual. The age, income, qualification of the individual are the main deciding factors for this. The savings and investment objective preferences of the respondents are shown in Table 3.

Table - 3

Objectives of Savings and Investment

\begin{tabular}{|l|c|c|}
\hline \multicolumn{1}{|c|}{ Objectives } & Weight Points & Rank \\
\hline To provide for Retirement & 340 & II \\
\hline For tax benefits & 286 & III \\
\hline Children's education & 356 & I \\
\hline Children's marriage & 242 & V \\
\hline To purchase assets & 260 & IV \\
\hline To meet contingencies & 196 & VI \\
\hline
\end{tabular}

While making a plan for savings and investment, individuals consider many factors. Apart from safety, liquidity and returns they consider other factors also. Capital appreciation, tax benefits etc., are the other factors generally investors take in to consideration. The respondents were asked to prioritize by giving 6 factors, 


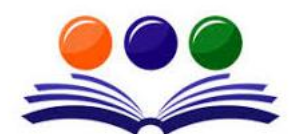

GRAND ACADEMIC PORTAL RESEARCH JOURNALS

\section{A GLOBAL JOURNAL OF SOCIAL SCIENCES}

( ISSN - 2581-5830 )

Impact Factor: SJIF - 4.998, IIFS - 4.375

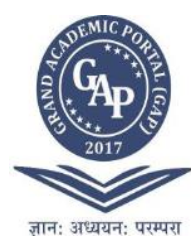

which they may consider most while taking savings and investment decisions. It is revealed that, the main objective of their savings and investments are for children`s education. From the Table 3 it is clear that with 356 weight points, this objective occupies first place. The second important objective of their savings and investments is to provide security for their retired life. With 340 weight points this occupies second place. To save the tax is in the third rank with 286 weight points followed by purchase of assets (260 weight points), children`s marriage (242 weight points) and to meet contingencies (196 weight points) are in the fourth, fifth and sixth place respectively. The point to be noted here that, respondents considered their children`s education is the most important aspect than any other objective. Instead of "earn and spend" culture, "earn, save and spend" culture is adopted by the respondents.

\subsection{Asset Preference}

While investing their surplus money, asset preference pattern varies from investor to investor. The respondents were asked to give ranking based on their preferred asset choice and it is stated in Table - 4 .

Table -4

Asset Preferences

\begin{tabular}{|l|c|c|}
\hline \multicolumn{1}{|c|}{ Assets } & Weight Points & Rank \\
\hline Bank deposits & 658 & I \\
\hline Life Insurance Products & 612 & III \\
\hline Postal Savings & 636 & II \\
\hline Real Estate & 512 & IV \\
\hline Gold & 329 & VIII \\
\hline Shares & 389 & VII \\
\hline Mutual Funds & 411 & VI \\
\hline Pension Funds & 405 & V \\
\hline Chit Funds & 184 & X \\
\hline Corporate Deposits & 264 & IX \\
\hline
\end{tabular}

It is revealed that, bank deposits are the most preferential choice of the respondents, occupied first rank with 658 weight points. The postal savings occupied second place with 636 weight points and life insurance products are in the third place with 612 weight points. Real estate, pension funds and mutual funds are in the $4^{\text {th }}, 5^{\text {th }}$ and $6^{\text {th }}$ place respectively with 512,411 and 405 grade points. Shares with 389 grade points are in the $7^{\text {th }}$ place followed by gold (329 grade points), corporate deposits (264 grade points) and chit funds (184 grade points) are in the $8^{\text {th }}, 9^{\text {th }}$ and $10^{\text {th }}$ place respectively. From the above it is clear that, the respondents sixth choice of investment is mutual funds. It shows that, investments in mutual funds is not their priority. But people are looking towards these products nowadays.

\subsection{Awareness about Mutual Funds}

Investments are made out of savings with an intention to get additional income or growth in value. Wealth creation is an essential thing for every one for future life. Therefore, investors should have knowledge about alternative investment avenues, how each of them perform, risk involved, etc. Risk averse people look generally bank deposits, postal savings, life insurance products and pension funds. Investment in stock market, mutual funds, bonds etc., and awareness about these is very less in our country comparatively to other countries. In our country just $2-3$ per cent of the population have invested in stocks. More or less it is same with that of mutual funds also.

Table - 5

Awareness About Mutual Funds

\begin{tabular}{|c|c|c|}
\hline Types of Respondents & No. of Respondents & Percentage \\
\hline Aware & 43 & 53.75 \\
\hline Not Aware & 37 & 46.25 \\
\hline Total & 80 & 100.00 \\
\hline
\end{tabular}

Among 80 respondents, 43(53.75 per cent) said that, they are aware of mutual funds and have little knowledge about the same and 37(46.25 per cent) are not aware of mutual funds.

Table - 6

Investments in Mutual Funds

\begin{tabular}{|c|c|c|}
\hline Invested in Mutual Funds & No. of Respondents & Percentage \\
\hline Yes & 18 & 22.50 \\
\hline No & 62 & 77.50 \\
\hline Total & 80 & 100.00 \\
\hline
\end{tabular}

Though 43 respondents are aware of mutual funds, only 18(22.50 per cent of the total) have invested in mutual funds. Remaining 77.50 per cent of the respondents have not made any investments in mutual funds. To popularize mutual funds investors education is necessary. 
